\title{
Digoxin's Interactions with Various Drugs and A Case Report
}

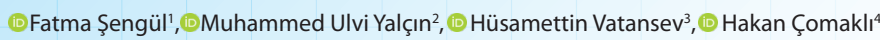

'Adıyaman Üniversitesi Eczacılık Fakültesi Biyokimya Anabilim Dalı, Adıyaman, Türkiye.

${ }^{2}$ Selçuk Üniversitesi Tıp Fakültesi Kardiyoloji Anabilim Dalı, Konya, Türkiye.

${ }^{3}$ Selçuk Üniversitesi Tıp Fakültesi Tıbbi Biyokimya Anabilim Dalı, Konya, Türkiye.

${ }^{4}$ Ankara Şehir Hastanesi, Kalp ve Damar Cerrahisi , Ankara, Türkiye.

\begin{abstract}
Digoxin is a drug commonly used to achieve rate control in heart failure and atrial fibrillation with some form of arrhythmia. It shows a positive inotropic effect by inhibiting the $\mathrm{Na}+/ \mathrm{K}+$ ATPase pump in the myocardial cell membrane. Since digoxin is a drug with a narrow therapeutic range, the therapeutic dose range should be monitored and the individual dose regimen should be established, taking care of plasma concentrations. Factors such as patient's age, renal dysfunction, abnormal electrolyte values, drug-drug or drug-plant interactions increase the risk of intoxication. Patients may present with nausea and vomiting in digoxin intoxication and may present with ventricular arrhythmias with fatal rhythm disorders. Although digoxin should be discontinued as treatment, accompanying electrolyte imbalances should be treated. In patients with malignant arrhythmias, digoxin-specific antibodies should be considered in treatment. In this study, various drug-drug interactions that are frequently observed and easily prevented in patients taking digoxin are discussed with a case report.

Keywords: digoxin, toxicity, drug interactions.
\end{abstract}

\section{Introduction}

Digoxin is basically a cardiac glycoside used in chronic congestive heart failure and treatment of some arrhythmias, characterized by a decrease in cardiac output, and characterized by systolic dysfunction of the ventricles ${ }^{1}$. However, since the therapeutic / toxic dose range $(0.8-2.0 \mathrm{ng} / \mathrm{mL})$ is narrow, digoxin poisoning can easily develop. When digoxin plasma concentration exceeds $2 \mathrm{ng} / \mathrm{mL}$, it causes toxic symptoms such as headache, gastrointestinal complaints (nausea, vomiting, etc.), visual dysfunction, irregular heartbeat, and diarrhea $^{2-4}$

\section{Case Report}

A 59-year-old woman with a history of diabetes mellitus, hypertension, hyperlipidemia, ischemic dilated cardiomyopathy, atrial fibrillation, and chronic obstructive pulmonary disease; She came to our hospital with the complaints of nausea-vomiting and general condition disorder. Her vitals were as following systolic blood pressure of $120 \mathrm{mmHg}$ and diastolic blood pressure of $80 \mathrm{mmHg}$, the respiratory rate of 18 breaths per minute, the pulse rate 50 beats / $\mathrm{min}$, the fever 36.7 degrees Celsius, and oxygen saturation of $89 \%$. It was learned from the anamnesis of the patient that she used carvedilol $2 \times 12.5$ $\mathrm{mg}$, ramipril 1x5 mg, spironolactone $1 \times 25 \mathrm{mg}$, rosuvastatin $1 \times 20 \mathrm{mg}$, and digoxin $1 \times 0.125 \mathrm{mg}$. The creatinine observed at the time of admission was $2.1 \mathrm{mg} / \mathrm{dl}$ and the serum digoxin level was $6.56 \mathrm{ng} / \mathrm{mL}$. The patient was considered digoxin intoxication accompanied by acute renal failure and digoxin was discontinued. Digoxin-specific antibodies were not considered in therapy, since the patient's hemodynamia was stable. The general condition of the patient with a Glasgow coma score of 12, blood gas and some respiratory parameters were $\mathrm{pH}: 7.33, \mathrm{PaO}_{2}: 33.9 \mathrm{mmHg}, \mathrm{PaCO}_{2}: 40.5 \mathrm{mmHg}, \mathrm{PaO}_{2} /$ $\mathrm{FiO}_{2}<200 \mathrm{mmHg}$. In the follow-up, the patient was given bronchodilator nebula treatment with a mechanical ventilator to improve his existing chronic respiratory disorders and general condition. The patient was treated with positive airway pressure from time to time. System examination: Cardiovascular system: S1 and S2 +, no additional sound, no murmur. Respiratory System: Both hemi thorax participate equally to breathing, basal ral +, no roncus. Gastrointestinal System: abdominal relaxed, no defensive rebound, no sensitivity. Other system examinations were normal. The patient was treated symptomatically, taking into account the results of biochemical and clinical research. On the 5th day of hospitalization, serum digoxin level was measured as $1.91 \mathrm{ng} / \mathrm{mL}$ and the patient left the mechanical ventilator due to the physical examination, blood gases and normal signs of life. The patient was discharged with cure on the 7th day of his application by organizing medical treatment of the patient, whose general

Corresponding Author: Fatma Şengül e-mail: fatmasengul245@gmail.com

Received: 13.02.2021 - Accepted: 10.12.2021

Cite this article as: Sengul F, Yalcin MU, Vatansev H, Comakli H. Digoxin's interactions with various drugs and a case report. Eurasian JTox. 2021;3(2):39-42. 


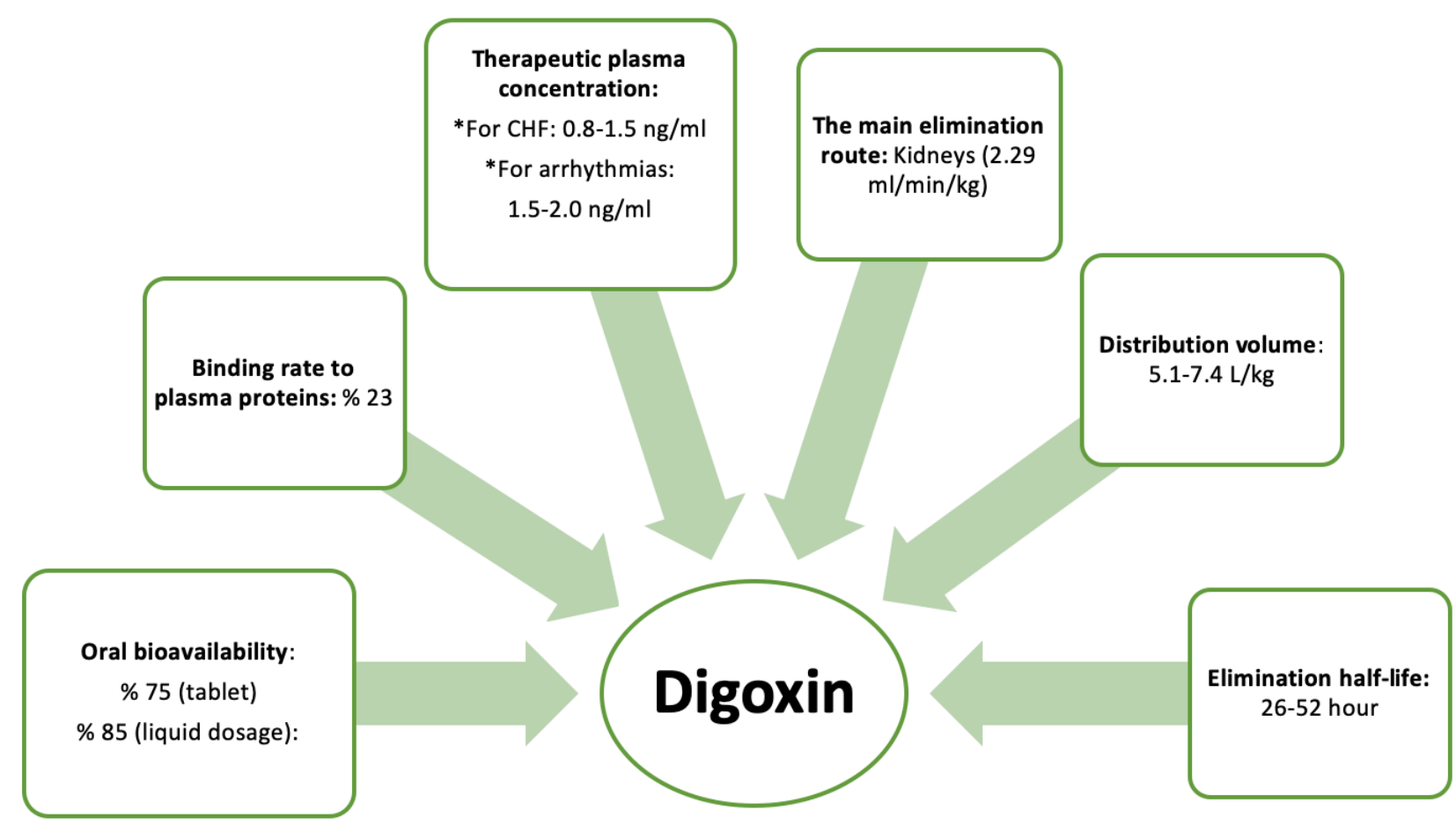

Figure 1: Pharmacokinetic properties of Digoxin (CHF: Congestive heart failure).

condition was good in the follow-up and his kidney functions decreased to normal.

\section{Discussion}

Although new treatment methods have been developed, the use of digoxin is a common agent that increases the contractile power of the heart. $\mathrm{Na}+$, which is located on the myocardial cell membrane, reversibly inhibits $\mathrm{K}+$ dependent ATPase pump and increases intracellular calcium level. In addition to its inotropic effect, it is distinguished from other inotropic agents and maintains its superiority with its slowing down heart rate and its recently revealed sympathetic feature. However, since the therapeutic / toxic dose range is narrow, digoxin intoxication can easily develop ${ }^{2-4}$.

Since digoxin has a narrow therapeutic range, serum levels; body weight, age, kidney function, liver failure, and changes in concomitant drug administration. A disrupted volume of digoxin distribution due to low renal function (digoxin is mainly excreted by the kidneys) or congestive heart failure may be one of the causes of digoxin toxicity ${ }^{5}$. Therefore, the pharmacokinetic properties given in Figure 1 should be considered when adding digoxin to treatment ${ }^{6}$.

ACE inhibitors, angiotensin receptor blockers, calcium channel blockers, antibiotics (erythromycin, tetracyclines, etc.), antiarrhythmias, $\beta$-blockers (carvedilol etc.), statins (rosuvastatine etc.), diuretics, antifungals, proton pump inhibitors, anticholinergic drugs, some psychiatric drugs, ivabradine, cyclosporine, diclofenac, ibuprofen, indomethacin, metformin, and acute renal failure increase serum digoxin concentration. If used with these drugs, the dose of digoxin should be reduced or the frequency of dosing chan$\operatorname{ged}^{7}$. In addition, hypokalemia greatly increases the tendency to digoxin intoxication; Thus, in a patient with severe hypokalemia, intoxication may occur at relatively low serum concentrations. For this reason, although the diagnosis can be supported by measurement of serum concentrations in many cases, the diagnosis of digoxin intoxication is largely made according to the clinic ${ }^{8}$. In addition, Eleutherococcus senticosus, Ginkgo biloba and Hypericum perforatum there is also interaction with plants ${ }^{9}$.

Drugs such as albuterol, antacids, cholestyramine, cholestipol, extenatide, kaolin-pectin, metoclopramide, miglitol, neomycin, penicillin, phenytoin, rifampin, sulfasalazine also reduce serum digoxin level ${ }^{7}$.

As mentioned above, kidney function, electrolyte values and medications of patients may be prone to digoxin intoxication. In our case, the patient applied to the emergency room with nausea and vomiting, and acute renal failure and the use of ramipril, carvedilol and spironolactone increased the susceptibility to digoxin intoxication with the interaction mechanisms given in Figure 2. In addition, the rates of increasing these drugs Serum Digoxin Concentration (SDC) are as follows: perindopril (58\%), metoprolol (16\%), spironolactone $(25 \%)$ and rosuvastatin $(22 \%)^{7}$. 


\begin{tabular}{|c|c|c|c|}
\hline$\beta$ - Blocker & ACE inhibitors & Rosuvastatine & Spironolactone \\
\hline $\begin{array}{l}\text { PD: } \beta \text { blockers } \\
\text { increase the } \\
\text { risk of } \\
\text { bradycardia } \\
\text { and AV block. } \\
\text { In addition, } \\
\text { serum } \\
\text { potassium } \\
\text { levels increase. }\end{array}$ & $\begin{array}{l}\text { PD: They cause } \\
\text { hyperkalemia, } \\
\text { which reduces } \\
\text { the cardiac } \\
\text { binding of } \\
\text { digoxin and } \\
\text { increase SDC. } \\
\text { - PK: Renal } \\
\text { excretion of } \\
\text { digoxin } \\
\text { decreases. }\end{array}$ & $\begin{array}{l}\text { PK: Vd of } \\
\text { digoxin and } \\
\text { kidney } \\
\text { clearance are } \\
\text { reduced. }\end{array}$ & $\begin{array}{l}\text { PD: This } \\
\text { diuretic and } \\
\text { digoxin } \\
\text { increases the } \\
\text { level of serum } \\
\text { potassium. } \\
\text { - PK: Digoxin } \\
\text { clearance } \\
\text { decreases. }\end{array}$ \\
\hline
\end{tabular}

Figure 2: Pharmacodynamic / pharmacokinetic interaction table of drugs that increase Serum Digoxin Concentration (Vd = Volume of distribution, PD: Pharmacodynamic interaction and PK: Pharmacokinetic interaction).

Among the major symptoms of acute digoxin intoxications, cardiac rhythm abnormalities, as well as frequent headaches, nausea-vomiting (possibly due to the direct effect of digoxin on the area post-medema in the medulla), visual function disorders, mental disorders, irregular heartbeat, low blood pressure and ventricular rhythm disturbances ${ }^{8,10}$. Patients can apply with nausea and vomiting in digoxin intoxication, as well as ventricular arrhythmias with fatal rhythm disorders. In our case, headache, visual disturbances, and low coma scale could not be evaluated due to intoxication findings. Nausea-vomiting, hypotension and severe ventricular arrhythmias were observed.

The findings following poisoning are directly proportional to the plasma concentration of digoxin. While the therapeutic dose of digoxin is $0.8 \mathrm{ng} / \mathrm{mL}$, when the plasma concentration is above $2 \mathrm{ng} / \mathrm{mL}$, signs of intoxication appear $^{2}$. After the acceptance of the case, the level of digoxin was measured as $6.56 \mathrm{ng} / \mathrm{mL}$ in the first serum sample taken. As the level of digoxin in the blood increases, Purkinje increases in automaticity. Accordingly, the foci that cause abnormal nerve stimuli gain efficiency and abnormal beats occur in the ventricular. The appearance of abnormal pulses is one of the first signs that digoxin plasma concentration has reached the toxic level by leaving the safety range ${ }^{3}$.

In digoxin intoxication, firstly, digoxin should be discontinued as a treatment in patients, but the accompanying electrolyte imbalances should be treated. If patients have malignant arrhythmias, digoxin-specific antibodies should be considered in treatment.

Bradyarrhythmias should be treated initially with atropine; If it is not successful, transvenous pacing or Fab antibody treatment should be started. If antiarrhythmic drug therapy is required, phenytoin and lidocaine are sometimes effective in suppressing digoxin-induced ectopic stimuli. If rhythm disturbances have occurred in the presence of hypokalemia, the potassium deficit should be carefully closed ${ }^{8,11}$. Potassium is administered orally or intravenously, according to the blood level.1 In the first controls performed on the patient, the $\mathrm{K}+$ level was measured as $5.35 \mathrm{mmol} / \mathrm{L}$ and potassium treatment was not performed since there was no critical decrease. Then, measured $\mathrm{K}+$ levels were observed normally.

Digoxine specific antibodies (Digibind) can be used as a powerful antidote in the presence of serious life-threatening arrhythmias. After the Fab fragments are administered intravenously, they bind specifically to the circulating digoxin molecules, forming the digoxin Fab antibody complex and inactivating them, allowing the signs of toxicity to regress rapidly ${ }^{12}$.

Digoxin-specific antibodies were not considered in therapy, since the patient's hemodynamia was stable.

\section{Conclusion}

As a result, digoxin and other digitalis glycosides are frequently used in the treatment of chronic heart failure and various arrhythmias. For this reason, patients should be informed about drug and food interactions that can lead to digoxin intoxication. For example, since hypokalemia greatly increases the tendency to digoxin intoxication, the patient should be warned to consume foods with high potassium content, while in the case of hypercalcemia, myocardium should be warned to restrict calcium consumption as it will increase sensitivity to digital. In patients using digoxin, which is a narrow therapeutic index drug, diseases such as hyperten- 
sion and hyperlipidemia are frequently observed, especially when prescribing, potential drug interactions should be paid attention and the patient should be periodically monitored for side effects and toxicity. Therapeutic drug monitoring will play an important role in reducing drug treatment problems, and patients will be able to use their medicines safely.

\section{References}

1. Şahinoğlu AH. Yoğun Bakım Sorunları ve Tedavileri. 3rd ed. Istanbul:Nobel Tıp Kitapevleri;2011.

2. Tekelioglu UY, Ayhan SS, Demirhan A, Ozturk S, Akkaya A, Yildiz I, et al. Digoxin Intoxication:A Case Report. Journal of Cardio-Vascular-Thoracic Anaesthesia and Intensive Care Society 2012;17(3):74-76.

3. Kayaalp SO. Rasyonel Tedavi Yönünden Tıbbi Farmakoloji. 10th ed. Ankara:Hacettepe Taş; 2002.

4. Adalet K. Klinik Kardiyoloji Tanı ve Tedavi. 2nd ed. Istanbul:İstanbul Tıp Kitabevi;2013.

5. Punniyakotti S, N BB. A Case Report on Digoxin Intoxication in a Clinical Pharmacist's Perspective. Asian J
Pharm Clin Res. 2018;11(4):1-3.

6. Wu AHB. Tietz Clinical Guide to Laboratuary Tests. 4th ed. USA:Elsevier;2006.

7. Lanoxin Tablets [Internet]. [Access date: 10 May 2019] https://www.rxlist.com/lanoxin-tablets-drug.htm\#interactions.

8. Hisar I. Kardiyolojide Klinik Problemler El Kitabı - Özetlenmiş Anahtar Referanslar ile. 5th ed. Ankara:Bilimsel Tıp Yayınevi;1995.

9. Hu Z, Yang $X$, Ho PCL, Chan SY, Heng PWS, Chan E, et al. Herb-drug interactions. Drugs. 2005;65(9):12391282.

10. Pita-Fernandez S, Lombardia-Cortina M, Orozco-Veltran D, Gil-Guillen V. Clinical manifestations of elderly patients with digitalis intoxication in the emergency department. Arch Gerontol Geriatr. 2011;53(2):106-10.

11. Çiftçi E, Aydın S. Toxicological Evaluation of Digital Glycosides in Congestive Heart Failure. Fabad Journal of Pharmaceutical Sciences 2018;43(3):263-77.

12. Chan, BSH, Buckley NA. Digoxin-specific antibody fragments in the treatment of digoxin toxicity. Clin Toxicol. 2014;52(8):824-836. 